\title{
HEMIONITIS FORMOSANA (HAYATA) CHRISTENH.A NEW RECORD TO THE PTERIDOPHYTICFLORA OF RAJASTHAN, INDIA
}

\author{
SHAHDAB HUSSAIN ${ }^{1}$, FATEN Z. FILIMBAN ${ }^{2}$ \& SHWETA YADAV ${ }^{3}$ \\ ${ }^{1}$ Department of Botany, Sangam University, Bhilwara -311 001 Rajasthan, India \\ ${ }^{2}$ Division of Botany, Department of Biology, College of Sciences, Centre for Medicinal, Aromatic and Toxic Plants, \\ King Abdualaziz University, Jeddah, 21551, Kingdom ofSaudi Arabia \\ ${ }^{3}$ Department of Botany, Sangam University, Bhilwara -311 001 Rajasthan, India
}

ABSTRACT
Hemionitisformosana(Hayata) Christenh.isa new record to the pteridophytic flora of Rajasthan. This new species is
reported for the first time from the Kumbhalgarh Wildlife Sanctuary of Rajasthan. Taxonomical descriptions,
photographs, distribution, and status are presented in this paper.
KEYWORDS: KumbhalgarhWildlife Sanctuary, Hemionitis

Received: May 24, 2021; Accepted: Jun 14, 2021; Published: Jul 02, 2021; Paper Id.: IJBRDEC20211

\section{INTRODUCTION}

Hemionitis L. is a genus of silver ferns in the Pteridaceae E.D.M. Kirchn. family. The 610.53-square-kilometer Kumbhalgarh Wildlife Sanctuary is located in the south central section of Rajasthan, between $25^{\circ}-25^{\circ} 40^{\prime} \mathrm{N}$ latitude and $73^{\circ} 2^{\prime}-73^{\circ} 30^{\prime} \mathrm{E}$ longitude. The sanctuary spans the districts of Udaipur, Pali, Ajmer, and Rajsamand in the state and serves as a distinct ecotone between the Aravallis highland forests and the Thar Desert in the west, acting as a barrier, preventing the desert from spreading eastward. The soil is mostly gravelly and sandy loam. The forest area is very undulating, with fragmented ranges of hills varying in elevation from 300 to 4000 feet above mean sea level. (Beddome 1883; Hope 1899; Ching 1935; Ching 1941; Copland 1947; Kanodia and Despande, 1962; Panigrahi 1960; Nayar 1962; Bir and Verma, 1963; Vyas, 1965; Mital, 1969; Sharma and Bhardwaja, 1976; Sharma et al., 1978; Gena et al., 1979; Bhardwaja et al., 1981; Wu 1981; Saiki 1984 a,b,c; Gena and Bhardwaja, 1984; Sharma et al., 1988; Wu 1990; Fraser Jankins 1997; Gena, 1998; Gastony and Rollo 1998; Yadav et al., 2002; Singh and Panigrahi 2005; Chaudhary and Dulawat, 2006; Chaudhary and Khichi, 2006; Zhang et al. 2007; Chandra et al. 2008; Punetha et al. 2008; Dulawat and Chaudhary, 2008; Yadav, 2010; Yadav et al., 2011. As currently known, this group, whose members are predominantly, though not all, shade and moisture loving plants are represented in the state by 21 genera and 43 species (Gena, 1998; Dulawat and Chaudhary, 2008; FraserJenkins and Dulawat, 2006 [Syn. Aleuritopteris formosana(Hayata) Tagawa] (Table 8- 14, Figure 1A - G)

Hemionitis formosana(Hayata) Christenh. Indian FernJ.1: 90 (1984).Cheilanthesanceps(Blanford) var. Brevifrons Khullar, Amer. Fem J. 66: 4, 1976. Aleuritopterispseudofarinosa Chinget S.K. Wu, ActaPhytotaxa. Sin.19: 72,1985.A summary of Indian Cheilanthoid ferns including the discovery of Nigripteris(Pteridaceae), an Afro-Arabic fern genus unknown to India, by Fraser-Jenkins and Dulawat. Fern Gazette, vol. 18, no. 15, pp. 216-226.

Rhizome short, erect, apex scaly; scales brown, bicolorous 0.39-0.85 mm road, 2.61-4.03 mm long; stipe length variable $8.0-12.3 \mathrm{~cm}$ long, dark-brown, thin, generally shorter or equal to the lamina. stipe scales $0.64-0.97 \mathrm{~mm}$ broad, 
2.58-3.52 mm long, brown, bicolorous (central region dark margin pale), linear lanceolate, margin entire, apex acute to acuminate, lamina $6.3-10.2 \mathrm{~cm}$. long, glossy, rachis scaly, scales as on rhizome but smaller and becoming concolorous; lamina pinnate or 2-pinnate, small, more or less oblong lanceolate, apex acuminate, texture thick, lower surface farinose, farina bright white, upper surface dark-green, glabrous; pinnae 6-9 pairs, sub-opposite to alternate, sessile, margin deeply lobed to the costa; basiscopic lobes (or pinnules)larger than the aeroscopic ones; lowest pinnae distant, of the same size as the 2-3 above, $3.0 \mathrm{~cm}$ long, $2.0 \mathrm{~cm}$ wide (at base), lobed shoulder to shore, basecopic lobes Costa and costuleglabrous: light-brown indussia, deep and uneven lobed edge, extremely shrinky, long, discontinuous. Long-displayed, 3.9-4.5 cm long, $2.6-3,5 \mathrm{~cm}$ wide, broadest over medium.

Spores: Brown, $52.5 \times 60 \mu \mathrm{m}$, globose, perinate, reticulate thickenings appearing like marginal projections.

Upper epidermis: Epidermal cells elongated sinuous, 40-75 $\mu \mathrm{m}$ broad 115-190 $\mu \mathrm{m}$ long; frond hypostomatic.

Lower epidermis: Epidermal cells isodimatric thin walled, sinuous, 25-35 $\mu \mathrm{m}$ broad, 90-150 $\mu \mathrm{m}$ long; stomata elliptic, 35 - $40 \mu \mathrm{m}$ broad, $40-45 \mu \mathrm{m}$ long, 2-6 epidermal cells surrounding

the stomata.

Stomata type: Anisocytic and diacytic.

Habitat: Grows in rock crevices at lower altitudes.

Distribution: Fort region and ParshuramMahadev hills.

Status: Rare

\section{DISCUSSION}

This protected region has been recorded for the first time with Hemionitis formosana (Hayata) Christenh. This suggests that there could be numerous more pteridophyte species in this protected area. New taxa are being added to the pteridophytic riches of Rajasthan, India, on a regular basis

\section{ACKNOWLEDGEMENT}

We express our thanks for the useful recommendations and critical remarks made by Dr. B. L. YadovMewarGangararar University (Chittorgarh) India. Sincere gratitude to Dr. Harish Nagar, Dean of the Khumbhalgarh Wildlife Sanctuary Basic and Applied Science and Forest School Department, for installations and permission to visit the sanctuary on a regular basis. The assistance and cooperation provided during the herbal consultations by BSI Western Circle, Pune team is duly recognised.

\section{REFERENCES}

1. Beddome, R.H. (1883).Handbook to the Ferns of British India: Ceylon and the Malay Peninsula. (Thacker, Spink, and Co., Calcutta with Supplement 1892)

2. Dheeraj Kumar Mishra, Devendra Pandey, S. S. Rathore, "Water Resources Development Action Plan for Nagzira Wild Life Sanctury, 33 Gondia District, Maharashtra Using Remote Sensing and GIS", International Journal of Civil, Structural, Environmental and Infrastructure Engineering Research and Development (IJCSEIERD), Vol. 4, Issue 5, pp, 31-38

3. Bhardwaja,T.N.;Gena,C.B.;Takker, T.; Kaur, R.andWadhwani, C. (1981). Newly recorded and rediscovered ferns at Mt. Abu. Journal of the Bombay Natural History Society, 87 , 639-640. 
4. Bhaswati Das, Saswata Saharia \& Pradip Sharma, "Geo-Ecological Change of Border Areas Between Khasi Hills and Southern Plains of Assam: A Case Study with Geomatics Approach”, International Journal of Environment, Ecology, Family and Urban Studies (IJEEFUS), Vol. 8, Issue 3, pp, 1-10

5. Bir, S.S. andVerma, S.C. (1963). Ferns of Mt. Abu. Research Bulletin of Punjab University.14,

187-202.

6. Chandra, S., Fraser-Jenkins, C.R.;Kumari,A.andSrivastava, A. (2008) A summary of the status of threatened Pteridophytes of India. Taiwania53(2): 170-209.

7. Rakshya Thapa, "Poaching Statistics of Rhinoceros Unicornis in Chitwan National Park, Nepal: A Review", International Journal of Applied and Natural Sciences (IJANS), Vol. 5, Issue 3, pp; 29-34

8. Chaudhary, B.L. and Dulawat, C.R., (2006). Distribution of Ferns and Fern-allies in SitamataWildlife Sanctuary, Rajasthan. Indian Fern Journal, 23, 75-82.

9. Chaudhary,B.L.andKhichi, Y.S.(2006). Ferns of Kumbhalgarh Wildlife Sanctuary in Rajasthan, India.Indian Fern Journal, 23, 83-91.

10. Mohammad Zakir Hossain Khan, "Disaster Impact on Sundarbans - A Case Study on SIDR Affected Area", IMPACT: International Journal of Research in Applied, Natural and Social Sciences (IMPACT: IJRANSS), Special Edition, pp, 5-12

11. Ching, R.C. (1935).IconesFilicumSinicarum, vol. 3. (Science Press, Beijing)

12. Ching, R.C. (1941). The studies of Chinese ferns, Part XXXI. Hong Kong Naturalist 10: 194

13. Clarke, C.B. (1880) A review of the ferns of Northern India. Transactions of the Linnean Society Series 2. Botany 1: 425-611. (Reprinted in book form by Bishen Singh and MahendraPalSinghDehradun and M/s. Periodical Experts, Delhi India in 1973).

14. Copeland, E.B. (1947) Genera Filicum. (CronicaBotanica Co., Waltham Massachusetts) FéeALA (1850-1852) Genera Filicum. descriptions and figures of the genera of Ferns. （Berger Levrault, Strasburg, Paris)

15. Dulawat, C.R., Chaudhary B.L., (2008). Selaginellaciliaris(Retz) Spring (Selaginellaceae: Pteridophyta) a new record for Rajasthan, India. Indian Fern Journal, 25, 106-109.

16. Fraser-jenkins, C.R.(2008). Taxonomic revision of three hundred Indian sub continental pteridophytes with a revised censuslist. Bishen Singh Mahendra Pal Singh, Dehradun.

17. Fraser-Jenkins, C.R. andDulawat C.S., 2009. A summary of Indian Cheilanthoid ferns and the discovery ofNegripteris(Pteridaceae), an Afro-Arabian Fern genus new to India. Fern Gazette, 18 (5), 216-229.

18. Fraser-Jenkins, C.R. (1997).New Species Syndrome in Indian Pteridology and ferns of Nepal.

19. Gastony, G.J.andRollo, D. (1995) Phylogeny and generic circumscriptions of cheilanthoid ferns (Pteridaceae: Cheilanthoideae) inferred from rbcL nucleotide sequences. American FernJournal85: 341-360.

20. Gastony, G.J.andRollo, D. (1998).Cheilanthoid ferns (Pteridaceae: Cheilanthoideae) in the South western United States and adjacent Mexico - a molecular phylogenetic reassessment of generic lines. Aliso 17: 131-144.

21. Gena, C.B.(1998). Systematics and taxonomy of Pteridophytes of Rajasthan. Indian Fern Journal, 15, 139- 148.

22. Gena, C.B. and Bhardwaja, T.N.(1984). Three new species ofIsoetes L. from Rajasthan, India. Journal of the Bombay Natural History Society, 81, 165-168. 
23. Gena, C.B., Bhardwaja, T.N.andYadav, A.K.(1979). A new species of Selaginellafrom India. American Fern Journal, 69 (4), 119-122.

24. Hope, C.W. (1899). The ferns of North-West India. Journal Bombay Natural History Society 12: 527-538. International Book Distributors, Dehradun

25. Kanodia, K.C.; andDespande, U.R.(1962). Additions to the flora of Mt. Abu, Rajasthan. Proceedings of IndianScience Congress Association. 49, 312-313.

26. Mital, P.L.(1969). Ferns and fern-allies of Rajasthan. Journal of the Bombay Natural History Society, 88, $31-42$.

27. Nayar, B.K. (1962). Ferns of India-6. Cheilanthes. Bulletin National Botanic Gardens Lucknow $\quad 68:$ 1-36.

28. Panigrahi, G. (1960). A note on Aleuritopterisgrisea(Blanf.) Panigrahi, comb. nov and A. anceps(Blanf.) Panigrahi comb. nov.Bulletin of the Botanical Survey of India 2: 321-322.

29. Punetha, N.;Bhakuni, K. andKholia, B. S. (2008) On the occurrence of Cheilanthesargentea(a silver fern) in central Himalaya. Journal of the Indian Botanical Society 87: 289-290.

30. Saiki, Y. (1984a). Notes on ferns 2. Asiatic species of the Aleuritopterisfarinosacomplex. Journal of Phytogeography and Taxonomy. 32: 1-13.

31. Saiki, Y. (1984b). Notes on Ferns 3. African and Neotropical species of the Aleuritopteris farinose group. Journal of Phytogeography and Taxonomy. 32: 81-90.

32. Saiki, Y. (1984c). Notes on ferns 4. Classification to the Aleuritopterisfarinosagroup. Journal of Phytogeography and Taxonomy 32: 91-98.

33. Sharma, O.P.andBhardwaja, T.N.(1976). Selaginellain Rajasthan, India. Fern Gazette, 11, 268.

34. Sharma, O.P.;Bhardwaja, T.N. andGena C.B. (1978). The genus OphioglossumL. in Rajasthan. Journal of the Bombay Natural History Society, 75, 938-939.

35. Singh, S.andPanigrahi G. (2005).Fern and Fern allies of Arunachal Pradesh, volsland2. (Bishen Singh Mahendra Pal Singh, Dehradun. India)

36. Vyas, L.N.(1965). Vegetation of Parsuram hills and its neighbourhood. Journal of Indian Botanical Society, 44, 149-162.

37. Wu, S.K. (1981). A study of the genus AleuritopterisFée in China. ActaPhytotaxonomicaSinica19: 57-74.

38. Wu, S.K. (1990).AleuritopterisFée. In Ching, R.C.andShing, K.H.Flora ReipublicaePopularisSinice3(1): 141-166. (Science Press, Beijing)

39. Yadav, B.L.andGoswami, H.K.(2010). A new pink brown OphioglossumL. from India. Bull.

Nat. Mus. Nat. Sci. Ser. B, 36, 4, 155-159.

40. Yadav, B.L.;MeenaD.K.; MeenaK.andHussain S.(2011). Selaginella reticulata (Hook. and Grev.) Spring (Selaginellaceae) A new record to the pteridophytic flora of Rajasthan, Northwest India. Journal of the Bombay Natural History Society, 108, 3,2011 .

41. Zhang, G.M.;Yang, W.L.andZhang, X.C. (2007). The identity of Aleuritopterisveitchiiand A. Duclouxiivar. sulphureain Sinopteridaceae. ActaPhytotaxonomicaSinica45 (3): 359-362. 


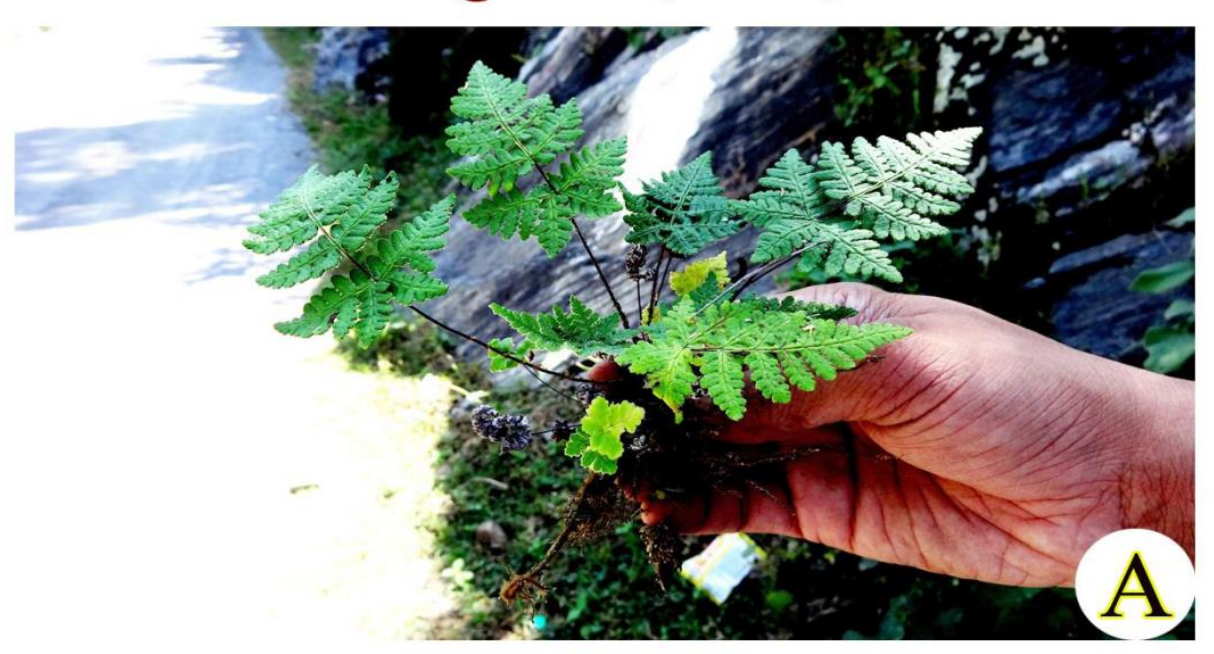

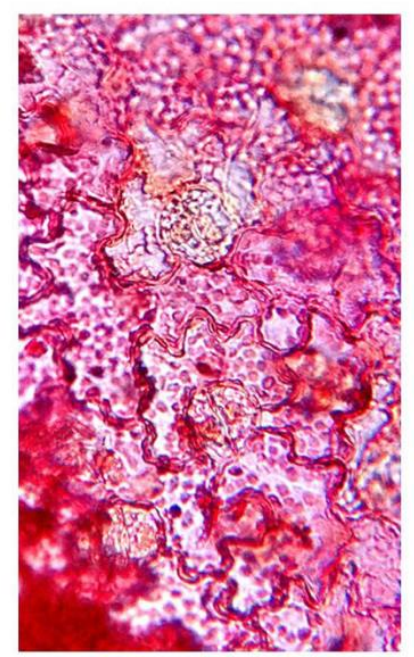

B

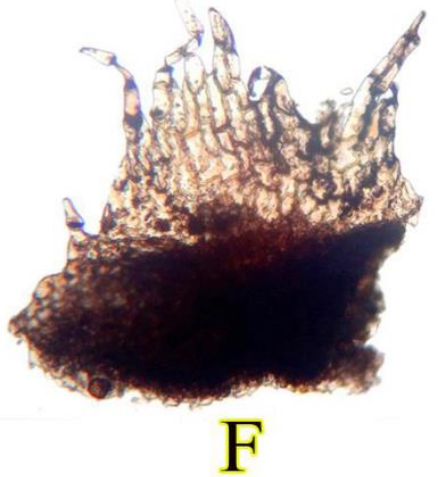

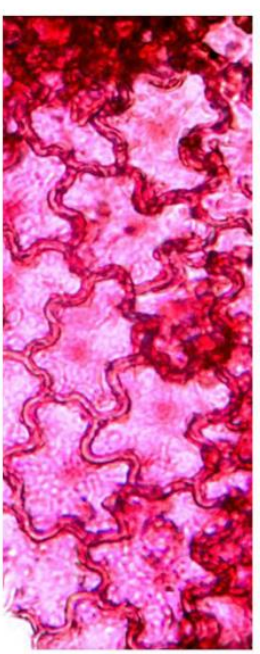

$\mathrm{C}$

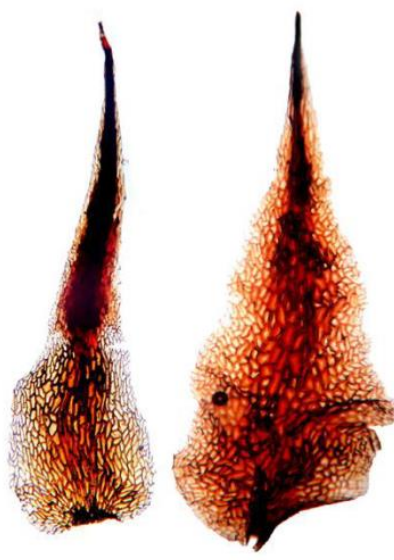

D E

Figure 1 (A-G) Morphological features of Hemionitis formosana(Hayata) Christenh.A. Hemionitis formosana(Hayata) Christenh.B. Stomata on upper epidermis.C.Stomata on lower epidermis.D. Stipescale.E.Rhizome scale.F.Indusium.G. Spores 
